\title{
Effect of Grain Teff, Sorghum and Soybean Blending Ratio and Processing Condition on Weaning Food Quality
}

\section{Menure Heiru*}

Department of Chemical Engineering, Dire Dawa University Institute of Technology, Dire Dawa, Ethiopia

\begin{abstract}
This study was conducted to evaluate the effect of grain teff, sorghum and soybean blending ratio and processing condition on weaning food quality with three specific objectives. Therefore, this study was initiated to address the protein energy malnutrition and sensory quality of weaning food. The proximate composition and sensory quality of blended samples were analyzed using standard methods. Processing condition had significant effect on nutritional and sensory properties of weaning food products. Moisture, ash, and crude fiber were significantly $(p<0.05)$ higher $(7.76 \%, 3.21 \%, 2.34 \%)$ respectivily. A significant high ash $(3.85 \%)$ crude protein $(17.50 \%)$ and crude fat $(16.33 \%)$ contents were observed in weaning food blend processed via fermentation. So, the proximate analysis results obtained from feremented blend $B_{1}$ showed significantly higher $(p<0.05)$ crude protien, ash and crude fat contents $(16.62 \%, 3.47 \%, 11.35 \%)$ respectively and lower fiber $(1.2 \%)$ content. The mean values of moisture, protein, fat, fiber, ash and carbohydrate were $4.19 \%, 17.17 \%, 14.33 \%, 1.26 \%, 3.11 \%$ and $59.91 \%$ respectively in fermented weaning foods. Sensory analysis revealed that highly acceptable product was obtained from fermented blends of teff, sorghum and soybean flour. The color, flavor, taste and overall acceptability scores of fermented blends were 5.72, 5.83, 5.77 and 5.77 (on 7- point hedonic scale), respectively. Among the treatments, fermented weaning food was found to produce acceptable weaning food gruel enriched by protein, ash and carbohydrate contents. So, fermented weaning food was enriched by proximate composition and acceptable sensory quality as compared to other processing conditions.
\end{abstract}

Keywords: Blending ratio; Soybean; Sorghum; Teff; Processing condition; Weaning food compositiont

\section{Introduction}

The growth and survival of infants after the recommended period of exclusive breast feeding for up to six months depend on the nutritional quality of the weaning food [1]. Breast milk is a sole and sufficient source of nutrition during the first six month of infant life. It contains all the nutrients and immunological factors infant require to maintain optimal health and growth. Towards the middle of the first year, breast milk is insufficient to support the growing infant. Therefore, nutritious complementary foods are needed to be introduced from six to twenty-four months of age [2]. These complementary foods are traditionally composed of staple cereals and legumes prepared either individually or as composite gruels [3], and they are supposed to serve as the main source of energy and nutrients for babies at weaning [1]. Teff (Eragrostisis tef (Zucc) Trotter) is one of the major and indigenous cereal crops in Ethiopia, where it is believed to have originated and has the largest share of area under cereal crop production [4]. It provides over two-thirds of the human nutrition in the country [5]. This cereal is considered high in nutritional quality, but limited information is available about its usefulness in weaning blends [6]. Teff flour is primarily used to make a fermented, sourdough type, flat bread called Injera [7]. Soybean (Glycine max) is a source of high quality cheap protein and polyunsaturated fatty acids that are often used to improve protein quantity and quality of most cereals and starch based foods. It is rich in iron, calcium and some B-vitamins though low in sulfur containing amino acids, methionine and cysteine [8]. Sorghum (Sorghum bicolor) (L.) Moench) is a critically important crop in subSaharan Africa on account of its drought tolerance. The main foods prepared with sorghum are: thin porridge (in Africa and Asia), stiff porridge (in West Africa), injera and bread (in Ethiopia), traditional beers (in Africa), baked products (in USA, Japan, and Africa), etc. In Africa, the majority of cereal-based foods is consumed in the form of porridge and naturally fermented products. Cereal-based thin porridge is prepared for fasting, sick or convalescent people, nursing mothers, and weaned infants [9].
Commercially made weaning foods are not available and if available most of them are priced beyond the reach of the majority of the population in less-developed countries. These foods are mostly manufactured using high technology and are sold in sophisticated packaging [10]. Such weaning foods may not be feasible in developing countries like Ethiopia due to limited income and inaccessibility. Therefore, there is a need for low-cost weaning foods which can be prepared easily at home and community kitchens from locally available raw materials such as sorghum, soybean and teff using simple technology like germination and fermentation. And, the most important nutritional problems in weaning foods consumed by the children in many parts of developing nations are protein energy malnutrition and deficient in essential macronutrients and micronutrients $[11,12]$. The high cost and inadequacy in production of protein-rich foods have resulted in increased protein energy malnutrition among children and other vulnerable groups in the developing world [13]. Therefore, this work was initiated to evaluate the effect of grain teff, sorghum and soybean blending ratio and processing condition on weaning food quality with the following specific objectives:

i. To determine the nutritional composition of weaning food blends of teff, sorghum and soybean.

ii. To determine the processing condition with the best potential for improving the nutritional quality of weaning food.

iii. To evaluate the sensory characteristics of weaning blends processed.

*Corresponding author: Menure Heiru, Department of Chemical Engineering, Dire Dawa University Institute of Technology, PO Box-1352, Dire Dawa, Ethiopia, Tel: +251-251-118682; E-mail: heirumenure782@gmail.com

Received February 07, 2017; Accepted February 27, 2017; Published March 03 , 2017

Citation: Heiru M (2017) Effect of Grain Teff, Sorghum and Soybean Blending Ratio and Processing Condition on Weaning Food Quality. J Food Process Technol 8: 659. doi: 10.4172/2157-7110.1000659

Copyright: (c) 2017 Heiru M. This is an open-access article distributed under the terms of the Creative Commons Attribution License, which permits unrestricted use, distribution, and reproduction in any medium, provided the original author and source are credited. 


\begin{tabular}{|c|c|c|c|c|c|c|}
\hline Ingredients & Moisture & Ash & Crude fiber & Crude fat & Protein \\
\hline Teff & $8.08 \pm 0.51^{\mathrm{a}}$ & $1.84 \pm 0.49^{\mathrm{b}}$ & $1.03 \pm 0.18^{\mathrm{b}}$ & $3.19 \pm 0.01^{\mathrm{b}}$ & $9.10 \pm 0.35^{\mathrm{b}}$ & \multicolumn{1}{c|}{ Carbohydrate } \\
\hline Sorghum & $7.80 \pm 0.71^{\mathrm{a}}$ & $1.41 \pm 0.13^{\mathrm{b}}$ & $1.77 \pm 0.12^{\mathrm{a}}$ & $2.83 \pm 0.09^{\mathrm{b}}$ & $7.87 \pm 0.17^{\mathrm{c}}$ & $78.29 \pm 0.95^{\mathrm{a}}$ \\
\hline Soybean & $5.39 \pm 1.24^{\mathrm{b}}$ & $4.75 \pm 0.83^{\mathrm{a}}$ & $1.98 \pm 0.18^{\mathrm{a}}$ & $22.88 \pm 0.37^{\mathrm{a}}$ & $27.00 \pm 0.89^{\mathrm{a}}$ & $37.98 \pm 1.34^{\mathrm{b}}$ \\
\hline \multicolumn{2}{|l}{} \\
\hline
\end{tabular}

Table 1: Proximate composition of grain teff, sorghum and soybean used in processing of weaning food (\%).

\section{Materials and Methods}

\section{Experimental materials}

Ingredients of the composite blends were acquired from the following sources: Teff and sorghum were obtained from MARC (Melkassa Agricultural Research Center) and soybean was obtained from AARC (Awassa Agricultural Research Center) that grown 2013/2014 crop years. All grains were stored at room temperature until analyzed.

\section{Weaning blend formulation}

Weaning blends were formulated in $60 \%$ cereals to $40 \%$ legume ratios, which yield the highest projected amino acid scores based on infant lysine requirements $\mathrm{FAO} / \mathrm{WHO} / \mathrm{UNU}$ [14]. Ingredients were weighed and formulated in proportions as follows: $\mathrm{B}_{1}(20 \%$ teff $+40 \%$ sorghum $+40 \%$ soybean $)$, and $\mathrm{B}_{2}(30 \%$ teff $+30 \%$ sorghum $+40 \%$ soybean $)$ and $\mathrm{B}_{3}(40 \%$ teff $+20 \%$ sorghum $+40 \%$ soybean $)$

\section{Processing methods}

Unprocessed control: All the test samples were cleaned, free from abnormal odors, broken seeds, dust and other foreign materials including living or dead insects before ground to flour. Sorghum and teff were milled in cyclone mill to a fine powder that able to pass through $\leq 250 \mu \mathrm{m}$ sieve size. Then the powder obtained was placed in plastic bag and stored at room temperature prior to blend. Soybean seed was grind to flour using grinding mill.

Natural fermentation: Fermentation was performed using the microorganisms naturally present on the grain. Slurries of the three composite blends $(1: 4 \mathrm{w} / \mathrm{v})$ were made from unprocessed control ingredients by mixing $200 \mathrm{~g}$ of flour with $800 \mathrm{~mL}$ of distilled water in a sterile beaker. Slurries were fermented in a temperature-controlled incubator at $30^{\circ} \mathrm{C}$ for $72 \mathrm{hrs} \mathrm{[15].} \mathrm{After} 72 \mathrm{hrs}$ fermentation period, the slurries were transferred into aluminum pans, and then oven-dried at $55^{\circ} \mathrm{C}$ for $48 \mathrm{hrs}$. Fermented dry blends were further milled in to fine flour using a home coffee grinder.

Germination/sprouting: Germination was performed in a dark room following the modified method Griffith et al. [16]. Sorghum and soybean seeds were rinsed and soaked in distilled water $(1: 3 \mathrm{w} / \mathrm{v})$ for $9 \mathrm{hrs}$. at ambient temperature $\left(23^{\circ} \mathrm{C}\right.$ to $\left.25^{\circ} \mathrm{C}\right)$. Seeds were dried and placed on perforated aluminum pans lined with filter paper, then placed in a dark, temperature controlled cabinet at $30^{\circ} \mathrm{C}$ for $12 \mathrm{hrs}, 24 \mathrm{hrs}$ and $36 \mathrm{hrs}$ germination. Germinating seeds were rinsed twice daily with distilled water to reduce microbial growth and to maintain adequate hydration. Sprouted seed was dried in forced air oven at $50^{\circ} \mathrm{C}$ for $20 \mathrm{hrs}$. Dried sprout sorghum and soybean were dehulled using mortar and pestle, and milled to flour by grinding mill.

\section{Proximate composition analysis}

Proximate composition of initial ingredients and blended samples of weaning food flour were conducted using standard methods. Moisture content, ash, and fiber content of ingredients and weaning blends were determined according to AOAC [17]. Protein was determined by
Micro-Kjeldal method AOAC [17]. Crude fat content was determined according to the method of AOAC [17] using soxlet apparatus and carbohydrate content was calculated as the percentage difference of proximate compositions.

\section{Sensory evaluation}

Sensory evaluation of the ready-to-eat formulated complementary foods (semi-liquid) were carried out on the taste, flavor, color and overall acceptability by 30 staff members, mothers and students using seven-point hedonic scale with score ranging from 'like extremely (7)' to 'dislike extremely (1)'in Food Technology and Process Engineering Laboratory of Haramaya University.

\section{Statistical analysis}

Analysis of variance (ANOVA) was used to test for significant differences between means of three replicate of blends and processing methods using the statistical analysis system.

\section{Results and Discussion}

\section{Proximate composition of grain teff, sorghum and soybean used in the weaning food}

The proximate composition of weaning food ingredients used in this experiment is shown in Table 1 . The moisture contents were $8.08 \%$, $7.80 \%$ and $5.39 \%$ for teff, sorghum and soybean respectively. The protein content of teff was $9.10 \%$, which was appreciably high compared to common cereals like maize, rice and sorghum. This value was lower than $10.7 \%$ reported by Laike [18]. Compared to other cereals, teff has higher protein content than maize $(8.3 \%)$, sorghum $(7.1 \%)$, barley (9.0\%), millet (7.2\%) and almost equivalent to wheat (10.3\%) [19]. The fat content of teff appeared to be lower than maize (4.6\%) but higher than wheat, barley and millet and equivalent to sorghum (2.8\%). Whereas the ash content was lower than millet and higher than others. Apparently, the ash content of teff observed in Gemechis variety was higher than sorghum (Teshale variety). Carbohydrate contents were $76.74 \%, 78.24 \%$ and $37.98 \%$ for teff, sorghum and soybean respectively. The carbohydrate content of Gemechies teff variety was in close agreement with National Research Council [20] content $72 \%$.

The proximate composition of sorghum used in the weaning food were $7.80 \%$ moisture, $1.14 \%$ ash, $1.77 \%$ crude fiber, $7.87 \%$ crude protein, $2.83 \%$ crude fat and $78.29 \%$ carbohydrate respectively. Carbohydrate content was high as compared to other common cereals and legumes. So, the nutritional content of sorghum grain in close agreement with other varieties of sorghum, i.e., it contains a reasonable amount of protein $(7.5 \%$ to $10.8 \%)$, ash (1.2\% to $1.8 \%)$, oil (3.4\% to $3.5 \%)$, fiber $(2.3 \%$ to $2.7 \%)$ and carbohydrate $(71.2 \%$ to $80.7 \%)$ with a dry matter ranged from $89.2 \%$ to $95.3 \%$ depending on the type of cultivars [21]. Such variations may be contributed by genotype, water availability, soil fertility, temperature and environmental condition during grain development Serna-Saldivar and Rooney [22]. The proximate composition of soybean was $5.39 \%$ moisture, $4.75 \%$ ash, and $1.98 \%$ crude fiber, and $27.00 \%$ crude protein, $22.88 \%$ crude fat and $37.98 \%$ total carbohydrate (Table 1). Famurewa and Raji [8] reported 


\begin{tabular}{|c|c|c|c|c|c|c|}
\hline B & Moisture & Ash & Crude fiber & Crude fat & Crude protein & Carbohydrate \\
\hline \multicolumn{7}{|c|}{ Control } \\
\hline B1 & $7.69 \pm 0.45^{a b c}$ & $3.47 \pm 0.15^{\mathrm{ab}}$ & $1.83 \pm 0.30^{\mathrm{cd}}$ & $10.02 \pm 0.34^{\text {def }}$ & $15.98 \pm 0.40^{d}$ & $60.98 \pm 0.63^{\mathrm{abc}}$ \\
\hline B2 & $7.39 \pm 0.36^{\text {cde }}$ & $3.18 \pm 0.17^{b}$ & $0.95 \pm 0.14^{g}$ & $9.63 \pm 0.11^{\text {ef }}$ & $16.14 \pm 0.35^{\mathrm{cd}}$ & $62.68 \pm 1.12^{\mathrm{ab}}$ \\
\hline B3 & $6.80 \pm 0.43^{e}$ & $3.16 \pm 0.16^{\mathrm{eb}}$ & $1.39 \pm 0.14^{\mathrm{ef}}$ & $8.83 \pm 0.38^{f}$ & $16.55 \pm 0.21^{\mathrm{bcd}}$ & $63.25 \pm 0.68^{a}$ \\
\hline \multicolumn{7}{|c|}{ Fermented } \\
\hline B1 & $4.85 \pm 0.49^{f}$ & $3.85 \pm 0.52^{\mathrm{a}}$ & $1.20 \pm 0.02^{\mathrm{fg}}$ & $14.14 \pm 0.85^{b}$ & $16.91 \pm 0.53^{\mathrm{abc}}$ & $59.02 \pm 0.82^{\mathrm{cd}}$ \\
\hline B2 & $3.42 \pm 0.18^{f}$ & $2.99 \pm 0.00^{\mathrm{bc}}$ & $1.26 \pm 0.13^{\mathrm{fg}}$ & $16.33 \pm 1.93^{a}$ & $17.50 \pm 0.35$ a & $58.47 \pm 2.17^{d}$ \\
\hline B3 & $4.31 \pm 0.34^{f}$ & $2.50 \pm 0.17^{d}$ & $1.31 \pm 0.03^{\mathrm{fg}}$ & $12.51 \pm 2.3^{c}$ & $17.10 \pm 0.44^{\mathrm{ab}}$ & $62.24 \pm 2.82^{\mathrm{ab}}$ \\
\hline \multicolumn{7}{|c|}{$12 \mathrm{hrs}$. Germinated blend } \\
\hline B1 & $7.04 \pm 0.23^{\mathrm{ed}}$ & $2.65 \pm 0.00^{\mathrm{cd}}$ & $1.61 \pm 0.05^{\text {def }}$ & $11.10 \pm 0.61^{\text {cde }}$ & $16.92 \pm 0.21^{\mathrm{ab}}$ & $60.68 \pm 0.58^{\mathrm{bcd}}$ \\
\hline B2 & $7.16 \pm 0.16^{\text {cde }}$ & $3.31 \pm 0.00^{\mathrm{b}}$ & $1.91 \pm 0.21^{c d}$ & $9.90 \pm 0.01^{\text {def }}$ & $16.48 \pm 0.25^{\mathrm{bcd}}$ & $61.21 \pm 0.17^{\mathrm{abc}}$ \\
\hline B3 & $7.29 \pm 0.63^{\text {cde }}$ & $3.48 \pm 0.17^{\mathrm{ab}}$ & $1.90 \pm 0.15^{\mathrm{cd}}$ & $11.04 \pm 0.29^{\text {cde }}$ & $16.90 \pm 0.54^{\mathrm{ab}}$ & $59.37 \pm 1.01^{\mathrm{cd}}$ \\
\hline \multicolumn{7}{|c|}{24 hrs. Germinated blend } \\
\hline B1 & $7.47 \pm 0.17^{\mathrm{bcd}}$ & $3.49 \pm 0.50^{\mathrm{ab}}$ & $2.09 \pm 0.14^{b c}$ & $10.96 \pm 0.21^{\text {cde }}$ & $16.63 \pm 0.17^{\mathrm{abc}}$ & $59.30 \pm 0.48^{\mathrm{cd}}$ \\
\hline B2 & $7.69 \pm 0.18^{a b c}$ & $3.17 \pm 0.14^{\mathrm{b}}$ & $2.43 \pm 0.34^{\mathrm{ab}}$ & $9.77 \pm 0.53^{e f}$ & $16.55 \pm 0.21^{\mathrm{bcd}}$ & $60.37 \pm 0.33^{\mathrm{bcd}}$ \\
\hline B3 & $8.12 \pm 0.15^{\mathrm{a}}$ & $2.98 \pm 0.00^{\mathrm{bc}}$ & $2.49 \pm 0.30^{\mathrm{ab}}$ & $10.27 \pm 0.13^{\text {def }}$ & $16.78 \pm 0.64^{\mathrm{abc}}$ & $59.34 \pm 0.56^{\mathrm{cd}}$ \\
\hline \multicolumn{7}{|c|}{36 hrs. Germinated blend } \\
\hline B1 & $7.30 \pm 0.33^{\text {cde }}$ & $3.90 \pm 0.34^{\mathrm{a}}$ & $1.75 \pm 0.38^{\text {cde }}$ & $10.51 \pm 0.19^{\mathrm{de}}$ & $16.90 \pm 0.14^{\mathrm{abc}}$ & $59.62 \pm 0.78^{\mathrm{cd}}$ \\
\hline B2 & $7.39 \pm 0.15^{\text {cde }}$ & $3.18 \pm 0.16^{b}$ & $2.36 \pm 0.43^{\mathrm{ab}}$ & $11.59 \pm 0.40^{\text {cd }}$ & $17.05 \pm 0.99^{\mathrm{abc}}$ & $58.41 \pm 1.98^{d}$ \\
\hline B3 & $8.03 \pm 0.20^{\mathrm{ab}}$ & $3.19 \pm 0.50^{\mathrm{b}}$ & $2.66 \pm 0.05^{a}$ & $10.06 \pm 0.58^{\text {def }}$ & $16.91 \pm 0.53^{\mathrm{abc}}$ & $59.11 \pm 0.75^{\mathrm{cd}}$ \\
\hline CV & 4.9 & 8.31 & 12.72 & 7.85 & 2.84 & 2.04 \\
\hline
\end{tabular}

All values are expressed as Mean \pm STDV of $\%$ dry basis except moisture (\% wet basis),

Values in a column with the same letter are not significantly different $(p<0.05)$.

Note: B: Blending; CV: Coefficient of variation in ( $\%) ; B_{1}: 20 \%$ teff $+40 \%$ sorghum $+40 \%$ soybean; $B_{2}: 30 \%$ teff $+30 \%$ sorghum $+40 \%$ soybean; $B_{3}: 40 \%$ teff $+20 \%$ sorghum $+40 \%$ soybean.

Table 2: Effect of blending ratio and processing condition on proximate composition of weaning food (\%).

that the proximate composition of soybean seed contains $40 \%$ protein, $21 \%$ oil $34 \%$ carbohydrate and $5 \%$ ash. The crude fat and ash content of soybean were in close agreement with Famurewa and Raji [8] but it varies in crude protein content. The variation in crude protein content might be the varieties, geographical location and soil fertility.

\section{Proximate composition of blended weaning food}

Effect of blending ratio and processing condition interaction on proximate composition of weaning food: The proximate composition of each weaning blends made by five processing method were summarized in Table 2. The moisture content of weaning blend varied significantly $(\mathrm{p}<0.05)$ among processing and blending methods. Moisture content of $24 \mathrm{hrs}$ germinated blend had highest (8.12\%) as compared to other processing methods. The interaction effect of blend was highest at 24 hrs germinated blend $\mathrm{B}_{3}(8.12 \%)$ and lowest $(3.42 \%)$ was observed in $\mathrm{B}_{2}$ of fermented weaning food. This was most probably due to dry matter losses. Furthermore, the values obtained for the moisture content and the associated dry matter of the weaning blend were suitable for an increase shelf-life of the food that was formulated from cereal and legumes. High moisture content aid microbial growth and reduce shelf-life of food products. Thus, the reduced moisture content of the weaning food especially the significant drop in the moisture content serve as a positive processing step that will improve the quality of the product [23]. These also reduce the cost of preservation and processing of the grain for both industrial and domestic uses.

The interaction effect of blending ratio and processing condition on ash content was highest in fermented and $36 \mathrm{hrs}$. germinated weaning food blend (B3) (3.81\%) and B1 (3.90) respectively and lowest (2.50\%) was in B3 of fermented weaning food flour. Lorenz [24] reported that ash content increases during germination to be apparent rather than true increases and resulted from the losses of dry matter. The interaction of blending ratio and processing condition had significant $(\mathrm{p}<0.05)$ effect on crude fiber content of weaning food flour (Table 2). The highest interaction effect on crude fiber content (2.66\%) was in $\mathrm{B}_{3}$ of $36 \mathrm{hrs}$ germinated weaning food blends and lowest $(1.20 \%)$ and $(1.26 \%)$ was in $B_{1}$ and $B_{2}$ of fermented weaning food flour. The crude fiber content of germinated soybean blended weaning food significantly increased as compared to unprocessed control weaning food flour. This is might be the decomposition of starch during germination to simple sugar. The expected decrease in crude fiber content during fermentation could be attributed to the partial solubilization of cellulose and hemicelluloses type of material by microbial enzymes and partly also by leaching. A previous study has reported a significant decrease of crude fiber contents after four days of maize fermentation [25]. The crude fiber content of infant food is expected to be low as foods with higher fiber content tend to cause indigestion in babies [26]. Hence sample with lower fiber content were rated good as potential weaning food. Fermentation as a process is promising to meet crude fiber stands in the preparation of weaning foods from locally available cereals. Crude fat content for all blends varied significantly $(\mathrm{p}<0.05)$ resulting from differences among individual ingredients and processing conditions. The highest crude fat content $(16.33 \%)$ was recorded in fermented blend and lowest $(8.83 \%)$ was for unprocessed control blends. Interaction effects of blend on crude fat content was highest (16.33\%) in fermented weaning food blend $\left(\mathrm{B}_{2}\right)$ and lowest $(8.83 \%)$ was in controlled weaning food flour at $\mathrm{B}_{3}$. Weaning blend formulation of soybean increases fat provided more concentrated calorie source rich in the essential fatty acid, linoleic acid. In reality desirable and more expensive oils are often consumed by household members other than the targeted child [3].

The interaction of blending and processing condition had significant $(\mathrm{p}<0.05)$ effect on protein contents (Table 2$)$. The highest protein content $(17.50 \%)$ was observed in fermented weaning food blend $\left(B_{2}\right)$ and lowest $(15.98 \%)$ was in unprocessed control blend $\left(B_{1}\right)$. The protein content of weaning blends was increased probably due to a reduction of phytic acid which might have contributed to the improved digestibility observed in germinated and fermented blends. Khetarpaul 


\begin{tabular}{|c|c|c|c|c|}
\hline Blend & Flavor/aroma & Taste & Color & Overall acceptability \\
\hline \multicolumn{5}{|c|}{ Unprocessed control } \\
\hline $\mathrm{B}_{1}$ & $5.50 \pm 0.90^{\mathrm{bc}}$ & $5.00 \pm 0.90^{c}$ & $5.36 \pm 0.49^{\text {cde }}$ & $5.16 \pm 0.74^{\mathrm{ef}}$ \\
\hline $\mathrm{B}_{2}$ & $5.00 \pm 1.08^{c d}$ & $5.50 \pm 0.90^{\mathrm{ab}}$ & $5.10 \pm 0.54^{\mathrm{e}}$ & $5.16 \pm 0.74^{\mathrm{ef}}$ \\
\hline $\mathrm{B}_{3}$ & $5.03 \pm 0.80^{\mathrm{cd}}$ & $5.63 \pm 0.96^{\mathrm{ab}}$ & $5.20 \pm 0.71^{\mathrm{de}}$ & $5.56 \pm 0.62^{\mathrm{bcd}}$ \\
\hline \multicolumn{5}{|c|}{ Fermented } \\
\hline $\mathrm{B}_{1}$ & $5.66 \pm 0.75^{b}$ & $5.83 \pm 0.69^{\mathrm{a}}$ & $5.50 \pm 0.50^{\text {cd }}$ & $6.00 \pm 0.00^{\mathrm{a}}$ \\
\hline $\mathrm{B}_{2}$ & $6.16 \pm 0.69^{a}$ & $5.83 \pm 0.37^{a}$ & $5.33 \pm 0.47^{\text {cde }}$ & $5.66 \pm 0.47^{\mathrm{abc}}$ \\
\hline $\mathrm{B}_{3}$ & $5.66 \pm 0.75^{b}$ & $5.66 \pm 0.95^{\mathrm{a}}$ & $6.33 \pm 0.47^{a}$ & $5.66 \pm 0.47^{\mathrm{abc}}$ \\
\hline \multicolumn{5}{|c|}{12 hrs. Germinated blend } \\
\hline $\mathrm{B}_{1}$ & $4.80 \pm 1.18^{d}$ & $5.80 \pm 0.61^{a}$ & $5.33 \pm 0.75^{\text {cde }}$ & $5.36 \pm 0.55^{\text {cdef }}$ \\
\hline $\mathrm{B}_{2}$ & $5.23 \pm 0.67^{\mathrm{bcd}}$ & $5.20 \pm 0.61^{\mathrm{bc}}$ & $5.36 \pm 0.66^{\text {cde }}$ & $5.26 \pm 0.63^{\text {def }}$ \\
\hline $\mathrm{B}_{3}$ & $5.23 \pm 0.85^{\mathrm{bcd}}$ & $5.56 \pm 0.72^{\mathrm{ab}}$ & $5.10 \pm 0.75^{\mathrm{e}}$ & $5.33 \pm 0.66^{\text {cdef }}$ \\
\hline \multicolumn{5}{|c|}{24 hrs. Germinated blend } \\
\hline $\mathrm{B}_{1}$ & $5.33 \pm 0.71^{\mathrm{bc}}$ & $5.43 \pm 0.67^{a b}$ & $5.36 \pm 0.49^{\text {cde }}$ & $5.46 \pm 0.86^{\text {bcdef }}$ \\
\hline $\mathrm{B}_{2}$ & $5.23 \pm 1.13^{\mathrm{bcd}}$ & $5.40 \pm 0.72^{\mathrm{ab}}$ & $5.66 \pm 0.54^{\mathrm{bc}}$ & $5.56 \pm 0.81^{\mathrm{bcd}}$ \\
\hline $\mathrm{B}_{3}$ & $5.23 \pm 0.77^{\mathrm{bcd}}$ & $4.83 \pm 0.69^{c}$ & $5.26 \pm 0.52^{\mathrm{de}}$ & $5.10 \pm 0.54^{f}$ \\
\hline \multicolumn{5}{|c|}{36 hrs. Germinated blend } \\
\hline $\mathrm{B}_{1}$ & $5.10 \pm 0.92^{\mathrm{cd}}$ & $5.56 \pm 0.81^{\mathrm{ab}}$ & $5.40 \pm 0.56^{\text {cde }}$ & $5.50 \pm 0.68^{\text {bcde }}$ \\
\hline $\mathrm{B}_{2}$ & $5.23 \pm 0.50^{\mathrm{bcd}}$ & $5.46 \pm 0.57^{\mathrm{ab}}$ & $5.66 \pm 0.47^{\mathrm{bc}}$ & $5.53 \pm 0.57^{\text {bcde }}$ \\
\hline $\mathrm{B}_{3}$ & $5.70 \pm 0.59^{b}$ & $5.63 \pm 0.66^{\mathrm{ab}}$ & $5.86 \pm 0.81^{\mathrm{b}}$ & $5.80 \pm 0.61^{\mathrm{ab}}$ \\
\hline Mean & 5.34 & 5.49 & 5.45 & 5.47 \\
\hline CV $(\%)$ & 15.83 & 13.55 & 10.98 & 11.54 \\
\hline
\end{tabular}

Table 3: Effect of blending ratio and processing condition interaction on sensory quality of weaning food.

and Chauhan [27] reported improved in-vitro protein digestibility during germination and while improvements in in-vitro protein digestibility with fermentation were associated with proteolytic enzyme production by micro-organisms. Abdelhaleem et al. [28] reported that the observed increment in protein content after fermentation was probably due to shift in dry matter content through depletion during fermentation by action of the fermenting microorganisms. However, cells of the fermenting microorganisms could have contributed to the protein, therefore, fermentation of weaning blend results in an observable increase in crude protein content. In most human diets, the protein is more limiting than others. Therefore, application of fermentation process that appears to increase the protein content even at the expense of other nutrients may be advantageous nutritionally [28]. Improvements in protein quality have also been documented after fermenting blended mixtures of plant-based complementary foods based on maize and legumes, groundnut and millet and cereal and soybean blends [29]. The improvement in protein digestibility after germination, dry heating could be attributed to the reduction of anti-nutrients such as phytic acid, tannins and polyphenols, which are known to interact with proteins to form complexes [30]. Carbohydrate content was determined by difference. The interaction of blending ratio and processing condition had significant $(\mathrm{p}<0.05)$ effect on carbohydrate content (Table 2). The highest (63.25\%) was recorded for controlled weaning food blend $\left(\mathrm{B}_{3}\right)$ and lowest $(58.41 \%)$ was observed in 36 hrs germinated blends of weaning food $\left(B_{2}\right)$. The processing method significantly decreases carbohydrate content of weaning foods. Moreover, fermentation and germination treatments decreased significantly the carbohydrate contents. The decrease in total carbohydrate content of weaning food ingredient may be the starch and simple sugars are the principal substrates for fermenting microorganisms; therefore, degradation and subsequent decrease in starch content are expected [25]. The decrease in carbohydrate content might be the degradation of sugar by processing conditions.
Effect of blending ratio and processing condition interaction on sensory quality of weaning food: The interaction effect of blending ratio and processing condition had significant $(p<0.05)$ effect in the color of weaning food (gruel). The color of the thin porridge made from fermented weaning blended flour was most preferred (like very much) by the panelists, while the thin porridge prepared from $12 \mathrm{hrs}$. germinated blend and control flour were least preferred for color (like slightly). The highest weaning food gruel color (6.33) was observed in $\mathrm{B}_{3}$ of fermented weaning food blend (like very much) and least (5.10) were obtained in $\mathrm{B}_{2}$ (like slightly) of control weaning food gruel. The interaction of processing condition and blending ratio were significant $(p<0.05)$ on weaning food flavor (Table 3$)$. The highest value of gruel flavor (6.16) was recorded in fermented weaning food gruel of $B_{2}$ (like very much) and lowest 5.00 was recorded in $\mathrm{B}_{2}$ of control weaning food gruel (like slightly). Also, interaction effect of processing condition and blending ratio had significant effect on taste of weaning food gruels. The highest value (5.83) was in fermented blend (B2 and B3) and lowest (5.00) was in B2 of control weaning food gruel. During fermentation the taste of weaning food gruel was preferred very much as compared to other processing conditions. The panelists however, noted that color, taste and overall acceptability of the gruel prepared were highly acceptable.

Overall acceptability of weaning food (gruel) were significantly $(\mathrm{p}<0.05)$ affected by processing condition and blending ratio (Table 3 ). The highest processing mean 6.00 (like very much) was recorded in fermented and lowest 5.10 (like slightly) was obtained in $24 \mathrm{hrs}$. germinated weaning food gruels. The highest (6.00) overall acceptability of weaning food was observed in fermented sample blended at $B_{1}$ and the lowest (5.10) was observed in the 24 hrs. germinated sample of blended at $\mathrm{B}_{3}$. Generally, sugar is by far the most important addition to complementary foods and is commonly added to improve the flavor and to encourage infants to eat while fat acts as flavor retainer and increases the mouth feel of foods [31]. Oil also improves the taste/flavor 
of the product and reduces bulkiness of starchy food in the mixture [31]. Germination also improves the consistency, mouth feel and taste of the product [32]. Inyang and Zakari [33] reported that sensory panelists are highly rated for formulations from germinated grains for all the sensory parameters investigated.

\section{Conclusion}

1. An infant weaning food of high nutrient density could be formulated and prepared from a combination of teff, sorghum and soybean. Blend formulation showed the strongest impact on nutritional quality and should receive attentions in the design and development of an infant weaning food.

2. The present study showed that blending ratio and processing condition significantly influenced the proximate composition, mineral content and sensory characteristics blended weaning food flour.

3. Processing conditions (fermentation and sprouting) were improved the proximate composition, mineral content and sensory quality weaning food (gruel).

4. Generally, the present result suggests that blending ratio and processing condition significantly improved the nutrient density and sensory quality of weaning foods.

\section{References}

1. Ogbeide ON, Ogbeide $O$ (2000) Mineral content of some complementary foods in Edo state, Nigeria. West Afri J Food and Nutri 2: 26-30.

2. Mamiro SP, Kolstreren P, Roberfroid D, Tatala S, Opsomer AS, et al. (2005) Feeding practices and factors contributing to wasting, stunting and iron deficiency anemia among 3-23 months old children in Kilosa District, Rura Tanzania. J Health Popul Nutri 23: 222-230.

3. Huffman SL, Martin LH (1994) First feedings: Optimal feeding of infants and toddlers. Nutri Res 14: 127-159.

4. Bultosa G (2007) Physico-chemical characterization of grain and flour in 13 te [Eragrostis tef (ZUCC.) Trotter] grain varieties. J Appli Sci Res 3: 2042-2051.

5. Uraga K, Narasimha HV (1997) Effect of natural fermentation on the HCLextractability of minerals from tef (Eragrostis tef). Bulletein of Chemical Society of Ethiopia 11: 3-10.

6. Cheverton MR, Chapman GP (1989) Ethiopian tef: A cereal confined to its centre of variability. In: Wickens GE, Haq N, Day P (eds.) New Crops for Food and Industry. Chapman and Hall, New York, pp: 235-238.

7. Davison J, McKnight C (2004) Teff demonstration plantings for 2003. FS 04-51. University of Nevada Reno Cooperative Extension, Reno, NV.

8. Famurewa JAV, Raji AO (2005) Parameters affecting milling qualities of undefeated soybeans. Inter J Food Eng 1: 6

9. Dicko MH, Gruppen H, Traore AS, Voragen AGJ, Van Berkel WJH (2006) Sorghum grain as human food in Africa: relevance of content of starch and amylase activities. Afri J Biotechnol 5: 384-395.

10. Kulkarni KD, Kulkarni DN, Ingle UM (1991) Sorghum malt-based weaning food formulations: Preparation, functional properties, and nutritive value. Food Nutri Bullet.

11. Brabin BJ, Coulter JBS (2003) Nutrition associated disease. In: Cook GC Zumla Al (eds.) Manson's Tropical Diseases. Saunders, London, pp: 561-580.

12. Millward DJ, Jackson AA (2004) Protein/energy ratios of current diets in developed and developing countries compared with a safe protein/energy ratio: Implications for recommended protein and amino acid intakes. Public Health Nutri 7: 387-405.
13. Otegbayo BO, Sobande FO, Aina JO (2002) Nutritional quality of soybeanplantain extruded snacks. Ecology Food Nutri 41: 463-474.

14. FAO/WHO/UNU (1985) Energy and protein requirements: Report of a Join FAO/WHO/UNU Expert Consultation. Tech. Rep. Ser. No. 724. World Health Organization, Geneva, Switzerland.

15. Chavan JK, Kadam SS (1989) Nutritional improvement of cereals by fermentation. Critical Rev Food Sci Nutri 28: 349-400.

16. Griffith LD, Castell-Perez ME, Griffith ME (1998) Effects of blend and processing method on the nutritional quality of weaning food made from select cereals and legumes. J Cereal Chem 75: 105-112.

17. AOAC (1990) Official methods of analysis. (16th edn), Association of Officia Analytical Chemists, Arlington, Virginia, USA.

18. Kebede L (2006) Effect of extrusion operating conditions on the physicochemica and sensory properties of grain teff puffed products. School of Graduate Studies, Haramaya University.

19. Asrat W, Frew T (2001) Utilization of Teff in Ethiopian diet. Narrowing the rift: Teff Research and Development, Proceedings of the International Workshop on Teff Genetics and Improvement, Debre Zeit, Ethiopia, pp: 239-243.

20. National Research Council (1996) Lost crops of Africa (Volume I: Grains) National Academy Press, Nutrition Society, Washington DC 56: 105-119.

21. Idris WH, Abdel Rahaman SM, El Maki HB, Babiker EE, Tinay AH (2007) Effect of malt pretreatment on $\mathrm{HCl}$ extractability of calcium, phosphorus and iron of sorghum cultivars. Inter J Food Sci Technol 42: 194-199.

22. Serna-Saldivar S, Rooney LW (1995) Structure and chemistry of sorghum and millets. In: Dendy DAV (ed.) Sorghum and millets chemistry and technology. American Association of Cereal Chemists, St. Paul, MN pp: 69-124.

23. Kikafunda JKL, Abenakyo, Lukwago FB (2006) Nutritional and sensory properties of high energy/nutrient dense composite flour porridges from germinated maize and roasted beans for child-weaning in developing countries: A case for Uganda. Ecology Food Nutri 45: 279-294.

24. Lorenz K (1980) Cereals sprout: Composition, nutritive value, food applications CRC Critical Review of Food Sci Nutri 28: 353-385.

25. Ejiqui J, Savoie L, Desrosies TM (2005) Beneficial changes and drawbacks of traditional fermentation process on chemical composition and anti-nutritional factors of yellow maize (Zea mays). J biol Sci 5: 590-596.

26. Olorunfemi OB, Akinyosoye FA, Adetuyi FC (2006) Microbial and nutritional evaluation of infant weaning food from mixture of fermented food substrates. Res J Biol Sci 1: 20-23.

27. Khetarpaul N, Chauhan BM (1990) Effect of germination and fermentation on in vitro starch and protein digestibility of pearl millet. J Food Sci 55: 883-884.

28. Abdelhaleem WH, El-Tinay AH, Mustafa Al, Babiker EE (2008) Effect of fermentation, malt-pretreatment and cooking on antinutritional factors and protein digestibility of sorghum cultivars. Pak J Nutri 7: 335-341.

29. Gibson RSL, Perlas-Hotz C (2006) Improving the bioavailability of nutrients in plant foods at the household level. Proceedings of the Nutrition Society 65 160-168.

30. Abbey TK, Alhassan A, Ameyibor K, Essiah JW, Fometu E (2001) Integrated science for senior secondary schools. Unimax Maxmillan Ltd, Accra North 75 $376-451$.

31. Walker AF, Pavitt S (2007) Energy density of third world weaning foods. Nutri Bulletin 14: 88-101.

32. Helland MH, Wicklund T, Narvhus JA (2002) Effect of germination time on alpha-amylase production and viscosity of maize porridge. Food Res Inter 35 : 315-321.

33. Inyang CU, Zakari UM (2008) Effect of germination and fermentation of pear millet on proximate, chemical and sensory properties of instant "fura": A Nigerian Cereal Food. Pak J Nutri 7: 9-12. 